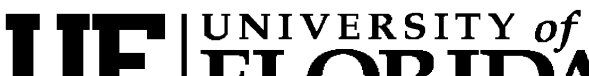 FLORIDA \\ IFAS Extension
}

\section{Culturally Diverse Advisory Boards and Volunteers ${ }^{1}$}

\section{Lisa A. Guion and Janet Harper Golden ${ }^{2}$}

This paper is the fourth in a series of articles on planning programs to effectively outreach to diverse audiences. This series will include specialized papers on enhancing cultural competence, recruiting diverse volunteers, planning culturally appropriate marketing strategies, and other topics that are integral to the design and implementation of culturally relevant Extension education programs.

\section{Overview}

Recognizing the community as important, and inviting community members to participate in all stages of programming is a first step toward building deeper relationships as well as stronger advisory boards and volunteers. In Extension, advisory committees and volunteers play key roles in making our programs more effective and relevant.

\section{Benefits of Culturally Diverse Volunteers and Advisory Boards}

Culturally integrated advisory boards are one vehicle for increasing community involvement. Integrated advisory boards allow Extension educators to gain invaluable information about what the community needs and expects. This makes Extension programs and services more relevant, connected, and meaningful (Nash, 1999).

Culturally diverse program volunteers are another valuable resource for educators. One role that culturally diverse volunteers and advisory committee members can serve is that of cultural guide (also called cultural brokers and cultural mediators in the literature). It is difficult, and may even be unrealistic, to expect an educator to know everything about all cultural groups in their county/area. Thus, cultural guides can highlight traditions, beliefs, practices, and other elements of a culture that may be unfamiliar to an educator (Lynch \& Hanson, 1997). Similarly, they can help the educator break through cultural barriers to connect on a more intimate level with diverse ethnic communities. For example, the cultural guide can assist the educator in making inroads and linkages with opinion leaders, gatekeepers, and leaders in the community. A cultural guide may be willing to engage in a teaching/learning process when approached from a position of equality and shared meaning. When professionals reach out and make genuine efforts to increase knowledge and awareness of others, they are often met with positive responses.

1. This document is FCS9220, one of a series of the Family Youth and Community Sciences Department, Florida Cooperative Extension Service, Institute of Food and Agricultural Sciences, University of Florida. Original publication date September 2005. Visit the EDIS Web Site at http://edis.ifas.ufl.edu

2. Lisa A. Guion, Ed.D., associate professor, Department of Family, Youth and Community Sciences, Florida Cooperative Extension Service, Institute of Food and Agricultural Sciences, University of Florida, Gainesville, FL 32611; and Janet Harper, M.B.A., 4-H Program Leader, Pinellas County Cooperative Extension Serivce, Institute of Food and Agricultural Sciences, Largo, FL 33774.

The Institute of Food and Agricultural Sciences (IFAS) is an Equal Opportunity Institution authorized to provide research, educational information and other services only to individuals and institutions that function with non-discrimination with respect to race, creed, color, religion, age, disability, sex, sexual orientation, marital status, national origin, political opinions or affiliations. U.S. Department of Agriculture, Cooperative Extension Service, University of Florida, IFAS, Florida A. \& M. University Cooperative Extension Program, and Boards of County Commissioners Cooperating. Larry Arrington, Dean 
However, there must be some level of caution in identifying the cultural guide because some individuals do not want to be viewed as "the voice" of their community (Robinson \& Howard-Hamilton, 2000; Ting-Toomey, 1999). Careful consideration and dialogue with an individual can ensure that the person does not feel as though he or she is a victim of tokenism.

To gain varying perspectives and capitalize on shared culture, Extension professionals should seek consultation with more than one cultural guide. Focusing solely on members of a group who hold formal offices or positions may not be the best strategy. It is important to remember that formal leaders of a community are not necessarily viewed as representing the best interests of the community; identifying informal leaders is important (Robinson \& Howard-Hamilton, 2000).

Cultural guides may prove invaluable in helping educators:

1. Plan how lessons are taught—maximizing learning style preferences;

2. Select activities and learning experiences that will be most effective and meaningful;

3. Design marketing approaches; and

4. Obtain other volunteers from within the cultural group (Lynch \& Hanson, 1997). The use of cultural guides will be covered in the EDIS fact sheet FY756, "Planning Programs to Break Down Cultural Barriers."

\section{Conclusion}

Just as Extension program participants should reflect the demographic make up of the county, our volunteers and advisory boards should be representative of all the citizens as well. Equally, if not more important, culturally diverse volunteers and advisory board members can assist educators in planning, designing, marketing, and implementing culturally relevant programs. They can also assist in increasing involvement and participation in programs.

\section{References}

Guion, L. A., Goddard, H. W., Broadwater, G., Chattaraj, S., \& Sullivan-Lytle, S. (2003).

Strengthening programs to reach diverse audiences. Gainesville, FL: Florida Cooperative Extension, University of Florida.

Lynch, E., \& Hanson, M. (1997). Developing cross-cultural competence ( $2^{\text {nd }}$ ed.). Baltimore, MD: Paul H. Brookes.

Nash, K. (1999). Cultural competence: A guide for human agencies. Washington, DC: Child Welfare League of America Press.

Robinson, T. L., \& Howard-Hamilton, M. F. (2000). The convergence of race, ethnicity, and gender: Multiple identities in counseling. Upper Saddle River, NJ: Prentice Hall.

Ting-Toomey, S. (1999). Communicating across cultures. New York: The Guilford Press.

\section{EDIS Fact Sheets in the Planning Culturally Relevant Programs Series}

1. Guion, L.A. (2005). An Overview of Diversity [Online]. EDIS. Florida Cooperative Extension Service, University of Florida. http://edis.ifas.ufl.edu/FY752

2. Guion, L.A. (2005). Reaching Diverse Audiences [Online]. EDIS. Florida Cooperative Extension Service, University of Florida. http://edis.ifas.ufl.edu/FY753

3. Guion, L.A., \& Brown, K. (2005). Culturally Competent Extension Educators [Online]. EDIS. Florida Cooperative Extension Service, University of Florida. http://edis.ifas.ufl.edu/FY754

4. Guion, L.A., \& Harper Golden, J. (2005). Culturally Diverse Advisory Boards and Volunteers [Online]. EDIS.Florida Cooperative Extension Service, University of Florida. http://edis.ifas.ufl.edu/FY755

5. Guion, L. A., \& Walker, N. (2005). Planning Programs to Break Down Cultural Barriers [Online]. 
EDIS. Florida Cooperative Extension Service,

University of Florida. http://edis.ifas.ufl.edu/FY756

6. Guion, L. A. (2005). Personal Marketing: A

Strategy for Marketing Programs to Diverse

Audiences [Online]. EDIS. Florida Cooperative

Extension Service, University of Florida.

http://edis.ifas.ufl.edu/FY757

7. Guion, L. A.,\& Kent, H. (2005). Ethnic

Marketing: A Strategy for Marketing Programs to

Diverse Audiences [Online]. EDIS. Florida

Cooperative Extension Service, University of

Florida. http://edis.ifas.ufl.edu/FY758

8. Guion, L. A., \& Kent, H. (2005). Relationship

Marketing: A Strategy for Marketing Programs to

Diverse Audiences [Online]. EDIS. Florida

Cooperative Extension Service, University of

Florida. http://edis.ifas.ufl.edu/FY759

9. Guion, L.A., \& Harper Golden, J. (2005).

Maximizing The Assets Of A Diverse Community

[Online]. EDIS. Florida Cooperative Extension

Service, University of Florida.

http://edis.ifas.ufl.edu/FY760

10. Guion, L. A. (2005). Enhancing Instruction

To Connect With Diverse Audiences [Online]. EDIS.

Florida Cooperative Extension Service, University of

Florida. http://edis.ifas.ufl.edu/FY761 